\title{
Menyoal Gangguan Kesehatan Mental Deviasi Seksual Fetish
}

\author{
Hadyan Zulkaisi Sukoco \\ Universitas Islam Negeri (UIN) Walisongo Semarang \\ hadyanzulkaisi@gmail.com \\ Faiq Althof \\ Universitas Islam Negeri (UIN) Walisongo Semarang \\ Falthof9@gmail.com \\ Ulin Nihayah \\ Universitas Islam Negeri (UIN) Walisongo Semarang \\ ulinnihayah@walisongo.ac.id
}

\begin{abstract}
This article aims to explain a dangerous form of sexual deviation where the perpetrator uses sexual gratification with sexually oriented inanimate or inanimate objects known as fetishes. Fetish behavior is a form of sexual deviation where the sexual activity carried out is carried out improperly to get sexual pleasure. This deviant behavior is very dangerous, because the perpetrators tend to use sexual objects that are unnatural or abnormal. Deviant sexual behavior if not above will lead to sexual behavior that is growing and even leads to prolonged stress. This is because the perpetrators cannot channel their deviant sexual desires and also have an impact on a person's mental health disorder. The research method used in writing this journal is a literature study based on case studies. The results of the analysis obtained data that fetish sexual deviation behavior in mental health can be treated through Islamic therapy to suppress deviations committed by perpetrators.
\end{abstract}

Keywords: Sexual deviation, fetish; mental health disorder 


\begin{abstract}
Abstrak
Artikel ini bertujuan untuk menjelaskan bentuk penyimpangan seksual yang berbahaya dimana pelaku menggunakan kepuasan seksual dengan benda mati atau tidak hidup yang berorientasi seksual yang dikenal dengan istilah fetish. Perilaku fetish merupakan bentuk deviasi sesksual dimana aktivitas seksual yang dilakukan tersebut dilakukan tidak sewajarnya untuk mendapatkan kenikmatan seksualnya. Perilaku penyimpangan ini sangat membahayakan, karena pelaku cenderung menggunakan obyek seks yang tidak wajar atau tidak normal. Perilaku seksual yang menyimpang apabila tidak bisa diatasi akan mengarah pada perilaku seksual yang semakin berkembang dan bahkan mengarah pada stress yang berkepajangan. Hal ini dikarenakan pelaku tidak bisa menyalurkan keinginan seksualnya yang menyimpang dan juga berdampak kepada gangguan kesehatan mental seseorang. Metode penelitian yang dilakukan dalam penulisan jurnal ini adalah studi kepustakaan dengan berbasis studi kasus yang terjadi. Hasil dari analisis didapatkan data bahwa perilaku deviasi seksual fetish dalam kesehatan mental bisa dilakukan terapi melalui terapi Islam untuk menekan penyimpangan yang dilakukan oleh pelaku.
\end{abstract}

Kata kunci: Deviasi seksual; fetish; gangguan kesehatan mental.

\title{
Pendahuluan
}

Masalah penyimpangan seksual merupakan permasalahan yang menjadi problem sosial di kalangan masyarakat. Masalah ini seperti fenomena gunung es, dimana permasalahan seolah-olah tidak terjadi, akan tetapi muncul kasus besar dipermukaan. Seringkali korban tidak melakukan pembelaan dan menganggap permasalahan penyimpangan yang terjadi sebuah hal yang wajar dan tidak jarang di tutup-tutupi oleh pelakunya sebagai aib.

Beberapa penyimpangan seksual yang telah banyak di beritakan oleh media massa, baik media cetak maupun media elektronik, turut meresahkan masyarakat. Hal ini sebagaimana yang terjadi pada sekitar tahun 2011, kasus penyimpangan seksual terkuak, dengan munculnya kasus sodomi yang dilakukan kepada anak jalanan dan pelaku bahkan sudah dilakukan dikenakan jerat hukum. ${ }^{1}$ Selain itu, munculnya kasus 
penyimpangan seksual dengan orientasi mencuri pakaian dalam wanita terjadi pada tahun 2014, dimana pelaku berdalih dengan ilmu hitam. ${ }^{2}$ Kasus deviasi seksual yang lain juga terjadi pada tahun berikutnya dimana pelaku bukan hanya mencuri pakaian dalam saja, tetapi juga sampai melukai alat vital objeknya. ${ }^{3}$ Bahkan pada pertengahan tahun 2020, media massa, dihebohkan dengan munculnya kasus penyimpangan seksual di kalangan akademisi, dimana pelakunya merupakan salah seorang mahasiswa. ${ }^{4}$ Pelaku melakukan dalih senioritas dengan meluapkan hasratnya dengan membungkus korbannya dengan kain jarik. Beberapa kasus penyimpangan seksual yang terjadi bukan terjadi secara tiba-tiba tetapi ditengarai karena adanya gangguan mental yang terjadi pada pelakunya

Jelas bahwa penyimpangan seksual bukanlah hal yang sepele. Hal ini dikarenakan beberapa kasus penyimpangan - penyimpangan seks yang menjurus kepada kejahatan seksual hingga bisa mengakibatkan kerugian material dan beban psikis yang mendalam bahkan juga kehilangan nyawa bagi sang korban. Kejahatan kesusilaan ini sudah begitu kompleks meresahkan dan mencemaskan masyarakat sehingga tidak dapat di pandang dari satu sisi terkecil saja.

Penelitian yang terkait dengan penyimpangan seksual bukan hanya dilakukan oleh penulis. Sebelumnya, sudah ada pembahasan terkait dengan studi kasus penyimpangan seksual terhadap anak di kepolisian daerah Istimewa Yogayakarta oleh Anggoro(2015) yang membahas terkait 3 permasalahan pokok dalam penelitiannya diantaranya terkait dengan pola kekerasan seksual, aspek perlindungan hukum dan upaya yang dilakukan dalam pencegahannya. ${ }^{5}$ Selain itu, pembahasan pendidikan seks terhadap pencegahan perilaku seksual pada remaja juga dibahas oleh Khoiroh Umah(2016), dimana menggunakan 30 responden dengan hasil ada pengaruh kuat pendidika seks terhadap pengetahuan tentang pencegahan perilaku menyimpang pada remaja. ${ }^{6}$ Bahkan pembahasan penyimpangan seksual berupa homoseks yang dibahas oleh Azwar(2020) dimana perilaku

\footnotetext{
2 https://news.detik.com/berita-jawa-barat/d-5191514/pencurian-celana-dalamwanita-di-cianjur-isu-kolor-ijo-menyeruak

3 https://news.detik.com/berita-jawa-barat/d-5191514/pencurian-celana-dalamwanita-di-cianjur-isu-kolor-ijo-menyeruak

4 Wel has/has dalam berita https://www.cnnindonesia.com/nasional/20200731084638-20-530908/kronologi-heboh-kasusfetish-gilang-bungkus-kain-jarik

5 Anggoro, Purwadi Wahyu, Korban kekerasan seksual: Studi Kasus penyimpangan seksual terhadap anak di kepolisian daerah istimewa yogyarata, Jurisprudence, Vol 5 No 1 juni 2015

${ }^{6}$ Khoiroh Umah, Teguh Saputro, Pendidikan seks terhadap epncegahan perilaku penyimpangan seksual pada remaja, Jurnal of Ners Community, Vol 7, No 1(2016)
} 
menyimpang homoseks diimplementasikan pada Studi Terhadap Pemikiran Ibnu Qayyim al-Jauziyah. ${ }^{7}$

Perilaku penyimpangan seksual yang terjadi, akan cenderung berdampak pada trauma psikologis terhadap korbannya. Salah satu perilaku menyimpang ini adalah yang terjadi pada kasus fetish. Fetish dianggap sebagai perilaku yang diwaspadai karena pelaku cenderung menggantikan aktifitas seksual pasangan kedalam aktifitas pasangan yang bersedia. Bahkan fetish dianggap sebagai bentuk penyimpangan yang berbahaya, karena hasrat pelaku terkadang bukan hanya berada pada benda mati, tetapi sebagai bentuk rangsangan seksual yang melibatkan gairah seksual yang diakibatkan oleh tubuh. Pelaku fetish bahkan menggunakan perilakunya dalam berhubungan dengan pasangannya, dengan mengharuskan pasangannya memakai pakai yang ketat untuk menumbuhkan rangsangan seksual yang dilakukan. Selain itu pasangan harus dicambuk atau dipukul, disiksa sedikit lebih dahulu, sehinga korban fetish pada umunya merupakan wanita.

Perilaku fetish yang bukan hanya merugikan korban tetapi juga meresahkan masyarakat memberikan stigma negatif yang diterima oleh pelaku fetish dan juga ex pelaku. Hasrat fetish yang berkepanjangan jika tidak bisa dihindari dan diatasi dikhawatirkan bukan hanya membahayakan korban tapi juga orang-orang yang berada disekitar pelaku. Oleh karena itu, penting bagi penulis untuk membahas terkait dengan deviasi seksual dan terapi yang bisa digunakan dalam meminimalisir bentuk deviasi seksual fetish. Metode studi pustaka ini merujuk pada literatur-literatur terkait deviasi seksual yang ada di Indonesia, kesehatan mental, dan pandangan agama. ${ }^{8}$

\section{Pembahasan dan Hasil}

\section{Konsep Kesehatan Mental}

Kesehatan mental merupakan sebuah kondisi yang ada pada diri seseorang, dimana seseorang terhindar dari gejala atau simtom yang berkaitan dengan gangguan jiwa dan gejala penyakit jiwa. Seseorang yang bermental sehat akan terhindar dari persaan cemas yang berlebihan, malas, kehilangan gairah untuk bekerja yang dapat menimbulkan adanya penyakit. Bahkan dewasa ini, dengan berkembangnya teknologi dan informasi gejala gangguan mental seseoarang semakin berkembang dengan adanya

\footnotetext{
${ }^{7}$ Azwar dkk, Strategi Terapiutik Korban Homoseks: Studi Terhadap Pemikiran Ibnu Qayyim al-Jauziyah, Islamic counseling Journal IAIN Curup, Vol 4 desember 2020

8 Arikunto, 2006, Prosedur Penelitian Suatu Pendekatan Praktek. Jakarta: PT. Rineka Cipta
} 
kegelisahan dan kehilangan ketentraman batin seseoarang yang menimbulkan problem kontradiksi dalam perilakunya.

Pengertian kesehatan mental Alexander Schneiders sebagai seni dalam mengembangkan dan menggunakan konsep dasar yang berkaitan dengan kesehatan mental, dimana pelaku malakukan penyesuaian diri dan mencegah dari gangguan psikologis yang ada. ${ }^{9}$ Selain itu pengertian kesehatan mental dijelaskan sebagai kondisi dimana seseorang terus tumbuh dan berkembang matang dalam kehidupannya, meneria segala tanggung jawab dalam dirinya serta menemukan penyesuaian saat berpartisipasi dalam memelihara aturan sosial dan tindakan dalam budayanya. ${ }^{10}$ Sehingga dapat diketahui bahwa konsep kesehatan mental bukan hanya pada penyesuaian diri seseorang tetapi bagaimana seseoarang bisa mengatasi gangguan psikologis, berinteraksi dengan sekitar dan melakukan penyesuaian demi memelihara tugas dan tanggung jawab yang diberikan.

Kondisi sehat merupakan kondisi yang diinginkan oleh seseorang. Akan tetapi, tidak jarang seseoarang didapati mengalami gangguan kesehatan mental atau biasa disebutkan dengan gangguan mental yang terkadang tidak disadari. Kaplan dan Sadock menyebutkan gangguan mental sebagai bentuk penyimpangan dari keadaan ideal suatu kesehatan mental. Contoh dari gangguan mental ini biasanya stres, frustasi dan lain sebagainya. ${ }^{11}$ Bahkan dalam berbagai penelitian menunjukkan adanya keterkaitan antara kesehatan fisik dan mental seseorang, dimana pada individu yang menderita sakit secara fisik menunjukkan adanya masalah psikis hingga gangguan mental. Sebaliknya, individu dengan gangguan mental juga menunjukkan adanya gangguan fungsi secara fisiknya. Berikut tujuan kesehatan mental yaitu :1. Mengusahakan agar manusia memiliki kemampuan mental yang sehat. 2. Mengusahakan pencegahan terhadap timbulnya sebab-sebab gangguan mental dan penyakit mental. 3. Mengusahakan pencegahan berkembangnya bermacam-macam gangguan mental dan penyakit mental. 4. Mengurangi atau mengadakan penyembuhan terhadap gangguan dan penyakit mental ${ }^{12}$ Mengenai fungsi mental hygiene bagi kehidupan manusia, bahwa mental hygiene itu memiliki fungsi pemeliharaan (preservation), pencegahan (prevertion), dan

\footnotetext{
${ }^{9}$ Syamsu Yusuf, Kesehatan Mental, Perspektif Psikologis dan Agama (Bandung: PT Remaja Rosdakarya, 2018), h. 10.

${ }^{10}$ Moeljono Notosoedirdjo, Latipun, Kesehatan Mental, Konsep dan Penerapan, Malang: UMM Press, 2014 h.25-26.

${ }^{11}$ Moeljono Notosoedirdjo, Latipun, Kesehatan Mental, Konsep dan Penerapan (Malang: UMM Press, 2014), h. 42.

${ }^{12}$ Siti Sundari, Kesehatan Mental Dalam Kehidupan (Jakarta: Rinekan Cipta, 2018), h. 
pengembangan (developmental) atau peningkatan (improvement) kondisi mental agar tercapai mental yang sehat. Dengan demikian, mental hygiene berfungsi untuk memelihara dan mengembangkan mental yang sehat dan mencegah terjadinya mental illness (mental yang sakit). ${ }^{13}$

\section{Konsep Deviasi Seksual}

Penyimpangan seksual (sexual deviation) atau abnormalitas seksual (sexual abnormality) atau ketidakwajaran seksual (sexual perversion) atau kejahatan seksual (sexual harrasment) merupakan sebuah bentuk dorongan yang berorientasi pada kepuasan seksual yang diperoleh dan ditunjukkan pada hal yang berkaitan dengan fantasi seksual dari pelaku, bisa melalui orgasme di luar hubungan kelamin, heteroseksual dan sebagainya. Secara normatif bertentangan dengan norma-norma tingkah laku seksual yang diakui masyarakat secara umum. Hal inilah yang mendasari asumsi, penyimpangan seksual sebagai bentuk penyalahgunaan fitrah kemanusiaan dan bertentangan dengan akal sehat. ${ }^{14}$

Perilaku seks menyimpang merupakan aktivitas seksual yang dilakukan tanpa adanya hubungan pernikahan. Penyimpangan seksual adalah aktivitas seksual yang dilakukan seseorang untuk mendapatkan kenikmatan seksual atau kepuasaan seksual dengan tidak sewajarnya. Biasanya, cara yang digunakan oleh orang tersebut adalah menggunakan obyek seks yang tidak wajar atau tidak normal. Penyebab terjadinya kelainan ini bersifat psikologis atau kejiwaan, seperti pengalaman sewaktu kecil, dari lingkungan pergaulan, dan faktor genetik. ${ }^{15}$

Organisasi Kesehatan Dunia (WHO) resmi menetapkan perilaku seks kompulsif atau kencanduan seks sebagai penyakit mental. Oleh Rose Mini (2020) menjelaskan bahwa kecanduan seks bila ia menunjukkan ketidakmampuan dalam mengendalikan dorongan seksual sehingga mengabaikan kesehatan dan tanggung jawab pribadi. Sama halnya permasalahan yang terjadi, bahwa kecanduan seks sama halnya kecanduan game, sehingga berdampak pada ketidanyamanan seseorang sehingga ia mengupayakan untuk melakukan hal tersebut. ${ }^{16}$

\footnotetext{
${ }^{13}$ Syamsu Yusuf, Kesehatan Mental, Perspektif Psikologis dan Agama (Bandung: PT Remaja Rosdakarya, 2018), hal 19

${ }^{14}$ Didi Junaedi. 2010. 17+: seks menyimpang. Jakarta:semesta raya merdeka

${ }^{15}$ Sarlito Sarwono. 2002. Psikologi remaja. Jakarta: raja Grafindo persada 16

https://amp.kompas.com/lifestyle/read/2010/05/01/20363317/bahaya.kecanduan.seks diakses $(15$
} 
Ketidakwajaran seksual atau deviasi seks itu mencakup perilakuperilaku seksual atau fantasi-fantasi seksual yang diarahkan pada pencapaian orgasme lewat relasi diluar hubungan kelamin heteroseksual, dengan jenis kelamin yang sama, atau dengan patner yang belum dewasa, dan bertentangan dengan norma- norma tingkah laku seksual dalam masyarakat yang bisa diterima secara umum. Penyimpangan seksual ini jelas merupakan substitusi dari relasi kelamin heteroseksual yang biasanya bersifat konfulsif, tegar dan menetap. Karena itu deviasi seksual dan disfungsi seksual merupakan satu aspek dari gangguan kepribadian dan penyakit neurotis yang umum. Pada seseorang mungkin terdapat penyimpangan seksual yang majemuk, sekalipun salah satu dari deviasi tersebut bersifat dominan. Misalnya gejala fetishisme dan ekshibisionisme biasa berbarengan dengan tingkah laku homoseksual ataupun homoseksualitas dan biseksualitas bisa bergandengan dengan heteroseksualitas yang memuaskan. ${ }^{17}$

Adapun sebab-sebab atau faktor deviasi seksual dengan menganut teori konfrehensi dapat diringkas sebagai berikut:

1. Sebab genetis atau faktor-faktor konstitusional yang herediter atau predisposisional.

2. Pengalaman- pengalaman anak pada usia kanak-kanak yang sangat mudah (tahun-tahun awal perkembangannya)

3. Proses belajar secara umum selama masa kanak-kanak.

4. Kejadian-kejadian yang berasosiasi dengan awal tingkah laku seksual pada usia pubertas adolesensi. ${ }^{18}$

Perilaku seksual yang menyimpang ini lebih banyak dikuasai oleh kebutuhan-kebutuhan neurotis dan dorongan-dorongan seksual daripada kebutuhan erotis, yang pada akhirnya menuntun pasien pada tingkah laku kompulsif dan patologis. Karena seksualitas itu erat dengan semua aspek kepribadian, maka penyimpangan seksualitas pada umumnya berasosiasi dengan:

1. Maladjustment (ketidakmampuan menyesuaikan diri)

2. Kesulitan-kesulitan neurotis

3. Ketakutan dan kecemasan terhadap relasi heteroseksual (relasi seksual dengan lawan jenis $)^{19}$

Perilaku seksual yang menyimpang pada seseoarang akan menjadi sebuah gangguan seksual jika sudah mengganggu seseorang dalam

\footnotetext{
${ }^{17}$ Yasir, Dekonstruksi Seksualitas Poskolonial, (Yogyakarta: LKIS, 2004) hlm.43

${ }^{18}$ Kartini Kartono, Psikologi Abnormal Dan Abnormalitas Seksual, (Bandung: cv. Mandar Maju, 2009) hlm 64

${ }^{19}$ Insar Annur, Tinjauan Kriminologis Dan Hukum Islam Terhadap Deviasi Seks Dalam Hal Kejahatan Seksual, (Makasar: UIN Alauddin, 2012) blm 40
} 
keberfungsiannya sehari-hari(menimbulkan stress menghambatnya dalam hubungannya dengan orang lain, dll). Bahkan Perilaku seksual seseorang bisa dikatakan tidak lazim jika ketertarikannya secara seksual adalah pada salah satu dari berikut ini : (a) bukan manusia, (b) orang dewasa yang tidak memberikan persetujuannya dalam aktivitas seksual tersebut, (c) anakanak, dan (d) tindakan seksual yang mempermalukan atau menyiksa dirinya ataupun partner seksualnya. ${ }^{20}$

\section{Terapi Deviasi Seksual Fatish pada Penderita Transeksual}

Parapbilia atau fantasi seksual yang menyimpang merupakan salah satu bentuk sexual disorder atau sexual deviation. Diagnostic and Statistical Manual of Mental Disorders (DSM) mengklasifikasikan beberapa bentuk paraphilia dalam DSM-III-R diantaranya adalah Fetisme, Pedofilia, Voyeurisme, dan "eksibisionisme". Dalam hal ini, fetish masuk dalam bentuk deviasi seksual.

Selain itu orienstasi seksual seseorang dimungkinkan karena adanya pornografi yang berkembang pada pelakunya. Sehingga Donald(2004) menjelaskan bahwa, pornografi yang dilakukan oleh pelaku deviasi seksual, mengakibatkan beberapa perilaku negatif, diantaranya:

1. Mendorong remaja untuk meniru melakukan tindakan seksual

Remaja dalam hal ini adalah masa dimana mereka mencoba hal yang baru. Dalam hal ini apa yang menjadi penghlihatan mereka akan cenderung menjaditiruan dan tuntunan mereka. Sehingga adanya keinginan dalam menduplikasi apa yang menjadi tontonan. Adapun para ahli menilai bahwa aktifitas seksual yang mereka lakukan sebelum mereka dewasa dipicu karena pengalaman dan melihat.

2. Membentuk sikap, nilai dan perilaku yang negative.

Pada masa perkembangannya, remaja yang cenderung mengkonsumsi konten pornografi akan menggambarkan apa yang menjadi pengalaman mereka dengan adegan seksual, sehingga dapat mengganggu proses pendidikan seksnya. Dalam hal ini dapat terlihat dari cara mereka memandang wanita, kejahatan seksual dan hubungan seksual pada umumnya. Sehingga secara personal, remaja akan berkembang menjadi serang yang merendahkan wanita secara seksual, memandang seks bebas sebagai perilaku normal dan alami, permisif terhadap perkosaan, bahkan cenderung mengidap berbagai penyimpangan seksual.

3. Menyebabkan sulit konsentrasi belajar hingga terganggu jati dirinya

\footnotetext{
${ }^{20}$ Ester Liawati, Penyimpangan seksual, jenis, penyebab dan penangannya. Makalah publikasi https://www.researchgate.net/publication/341463915_PENYIMPANGAN_SEKSUAL_JENI S_PENYEBAB_DAN_PENANGANANNYA 2020
} 
Pornografi yang menjadi pengalaman penglihatan mereka akan memberikan fantasi seksual yang akan mengendapkan kesan mendalam dibawah otak sadar, sehingga mereka akan cenderung sulit berkonsentrasi, tidak fokus, malas belajar, tidak bergairah melakukan aktivitas yang semestinya, hingga mengalami shock dan disorientasi (kehilangan pandangan) terhadap jati diri mereka sendiri bahwa sebenarnya mereka masih remaja.

\section{Tertutup, dan tidak percaya diri}

Remaja pecandu pornografi yang mendapat dukungan temantemannya sesama penggemar pornografi, akan terdorong menjadi pribadi yang permisif (memandang maklum) terhadap seks bebas dan mereka melakukan praktek seks bebas di luar pantauan orang tua. Sedangkan remaja pecandu pornografi yang dikelilingi oleh teman-teman yang terbimbing dan bebas dari pornografi, akan cenderung merasa minder dan tidak percaya diri. ${ }^{21}$

Maslow meyakini bahwa tingkah laku manusia bisa diterangkan dengan memperhatikan individu yang penuh makna dalam hal ini individu untuk mencapai tujuan-tujuan personal yang membuat kehidupan bagi individu yang bersangkutan penuh makna dan memuaskan. Maslow melukiskan manusia sebagai makhluk yang tidak pernah berada dalam keadaan sepenuhnya puas, dan bahwa kebutuhan yang ada pada manusia merupakan bawaan, tersusun menurut tingkatan atau bertingkat. Dalam mencapai kebutuhan untuk mencapai kesehatan mental manusia perlu adanya motivasi-motivasi, Maslow membedakan antara tingkah laku yang seringkali tidak dimotivasi (ekspresifsive behavior) dan dengan tingkah laku yang selalu dimotivasi untuk memenuhi sebuah kebutuhan (tingkah laku penanganan).

Jika diimplementasikan pada pelaku deviasi seksual, fetish dimana Penggunaan benda (fetish) yang lebih disukai atau sebagai satu-satunya cara untuk mendapatkan kegairahan seksual. Benda itu tidak terbatas pada perangkat pakaian wanita atau alat-alat perangsang gairah seksual (seperti vibrator). Sehingga orang yang mempunyai gangguan fetish bisa diberikan terapi motivasi dalam merubah pandangan hidupnya terkait dengan orientasi seksual yang dilakukan. Ada kemungkinan orang yang mempunyai gangguan mental dengan bentuk deviasi seksual fetish ini, awalnya tidak bisa mengaktualisasikan diri dengan baik sehingga orientasi perkembangan

${ }^{21}$ Mulya haryani, Dampak Pornografi Terhadap Perilaku Siswa Dan Upaya Guru Pembimbing Untuk Mengatasinya, Jurnal ilmiah Konselor, Vol 1, No 2(2012) 
individu dari pelaku mengarah kepada orientasi yang bersifat negatif berupa penyimpangan seksual.

Selain itu, jika dilihat dari konsep psikoanalisa, bahwa orang yang interaksi yang dilakukan oleh individu, akan mempengaruhi kesehatan mental seseorang. Dalam hal ini faktor epigenetik dimana kematangan diri secara psikologis seseorang yang berkembang seiring pertumbuhan fisik dalam tahap-tahap perkembangan individu, juga merupakan faktor penentu kesehatan mental individu.

Orang yang mempunyai deviasi seksual fetish sebenarnya bukan orang yang mempunyai gangguan yang tanpa sebab. Proses kematangan perkembangan pertumbuhan pelaku yang tidak wajar menjadi salah satu penyebab. Ketidak mampuan pelaku fetish dalam mengorientasikan fantasi seksual dan tugas perkembangan yang tidak paripurna menjadikan orientasi seksual pelaku tidak terpenuhi sesuai dengan kapasitasnya. Dampaknya, orientasi seksual ini diimplementasikan dengan benda mati yang di fantasikan dengan objek seksual pelaku.

Bentuk terapi yang ditawarkan dalam mengatasi perilaku transeksual diantaranya:

1. Pembiasaan dari respon yang berlawanan (condistioning of comparable respon) Maksud dari teknik ini adalah penciptaan respon yang disesuaikan dengan apa yang diterima oleh pelaku yang diimplementasikan dengan memperbaiki timbulnya gejala penyimpangan seksual. Pembiasaan terhadap penekanan respon yang dilakukan dengan melawan respon yang salah ditujukan untuk menghapus pembiasaan yang ada pada diri pelaku.Pada metode ini pembiasaan yang dilakukan dengan befikir, bertindak dan beraktifitas sebagaimana manusia normal pada umumnya untuk mendapatkan kesembuhan secara maksimal di dalam dirinya.

2. Teknik menghentikan kecemasan

Pembiasaan yang dilakukan oleh pelaku penyimpangan seksual dengan memberikan kejutan aliran listrik yang rendah pada lengan bawah penderita. Metode ini dilakukan untuk memberikan kejutan dan bisa menghentikan aliran listrik bila terlalu nyeri. Pemberian kejutan listrik ini disertai dengan melantunkan kata istgfar (astaghfirullabal 'adriim) akan menimbulkan rasa lega dan sadar. Selanjutnya pelaku dinasehati secara berkesinambungan untuk sering mengucapkan kata-kata tersebut. Metode ini dapat diterapkan pada pelaku penyimpangan seksual dengan mengurangi tingkat kecemasan dengan banyak memohon ampun banyak mengucapkan istighfar.

3. Mencontoh dan meniru 
Mencontoh dan meniru telah terbukti dapat membiasakan orang yang mengalami gangguan penyimpangan seksual yaitu dengan cara mengamati atau melihat seseorang yang dapat diteladani. Orang tua, guru dan teman dekat dapat dijadikan sebagai contoh dalam menghilangkan kebiasaan perilaku penyimpangan seksual. Pada metode ini, pelaku akan diminta untuk bergaul dengan orang-orang baik dan shaleh, kemudian pelaku diminta untuk mengamati dan mengikuti pola perilaku orang-orang yang baik tersebut. Biasanya metode ini sangat cocok untuk diterapkan di lingkungan agamis seperti pondok pesantren.

4. Pembiasaan positif

Terapi dengan pembiasaan positif adalah dengan cara membiasakan dari mulai berbicara, bergerak bertingkah laku maupun berfikir semuanya harus berfikir positif (positif thinking). Ketika seseorang selalu berfikir positif, dia tidak akan mudah menyalahkan siapapun di dalam kehidupannya. Para pelaku penyimpangan seksual, dari mulai menyadari bahwa dirinya mengalami kelainan seksual pada saat itu juga harus bisa menyadari bahwa semuanya itu adalah menjadi bagian dari kehendak Allah dan apa yang terjadi di dalam dirinya itu merupakan akibat dari pendidikan yang salah pada masa-masa sebelumnya. Ketika diawali dengan berfikir positif, maka segala tindakan yang dilakukan pun akan menjadi positif.

Faktor-faktor lain yang mungkin terkait, yaitu mengalami pelecehan seksual dan emosional pada masa kanak-kanak, atau kesenangan seksual di masa kecil. Sebagian pelaku juga memiliki penyimpangan seksual lainnya. Seseorang mungkin saja mengalami eksibisionis jika memenuhi kriteria berikut

1. Memiliki fantasi, dorongan atau perilaku yang berulang untuk meningkatkan gairah seksual dengan memperlihatkan alat kelamin pada orang asing setidaknya selama 6 bulan.

2. Merasa sangat tertekan atas dorongan untuk melakukan perilaku tersebut sehingga tak dapat menjalani kehidupannnya dengan baik (termasuk dalam keluarga, lingkungan, ataupun pekerjaan).

Diagnostic and Statistical Manual of Mental Disorders (DSM) IVTR, parafilia merupakan bentuk gangguan yang mencangkup ketertarikan seksual terhadap objek yang tidak wajar atau aktifitas seksual yang tidak pada umumnya dengan kata lain terdapat deviasi (para) ketertarikan seseorang (filia). ${ }^{22}$ Bentuk DSM ini seperti yang terjadi pada pelaku fetish yang dalam beberapa kasus sering memanfaatkan korbannya untuk

${ }^{22}$ Morgan, Clifford Thomas, 1986, Introduction to Psychology (International Edition), McGraw-Hill Book Co, Singapore, h. 28 
memuaskan hasrat dalam seksualnya. Bahkan pada beberapa kasus korban tidak melakukan pelaporan bahkan tidak jarang orang yang mengidap fetish jelas telah melakukan pelanggaran terhadap hak orang lain. berikut:

Bentuk-bentuk terapi lain yang dapat digunakan adalah dengan cara

1. Cara pengenalan diri dan tindak otoriter diri

Di dalam otak manusia, di dalamnya berbentuk susunan sel-sel yang terkoordinasi dengan sempurna sehingga bisa menghasilkan proses berfikir. Selanjutnya, proses berfikir ini disebut sebagai pikiran. Pikiran inilah yang memutuskan segala sesuatunya. Kemudian, di dalam jiwa manusia terdapat yang namanya nurani, norma-norma, aturan hakiki, keyakinan, naluri, suara hati atau bisikan hati adalah merupakan sebentuk pemberi pertimbangan kepada proses berfikir yang dilakukan oleh otak. Hasilnya, suatu keputusan bisa diputuskan atau tidak. Metode ini caranya, adalah dengan mencoba membuang jauh pikiran-pikiran yang berhubungan dengan penyimpangan seksual apalagi sampai pada perilaku waria. Jika masih terlalu sulit dan merasa tidak mampu, cobalah untuk memikirkan hal lain selain hal tersebut. Atau lakukan istigfar (astagfirullah) atau dengan mengucap Allahuakbar berkali-kali. Lakukan hal tersebut ketika sedang melamun atau sebelum tidur.

2. Terapi sugesti

Cobalah mengucapkan dengan lirih atau dalam hati (sugesti) kalimat-kalimat berikut ini (atau dengan menciptakan kalimat yang lain), seperti: "Transeksual menjiijikan, transeksual sesat, aku bukan pelaku transeksual, aku manusia normal." Ucapkan salah satu kalimat di atas berkali-kali sambil membayangkan apa yang sedang diucapkan. Terjanglah pikiran liar yang melawan atau sebentuk kebosanan. Terus bunyikan seperti seorang sedang wiridan dengan khusuk. Ucapkanlah minimal 2.000 kalimat dalam sehari. Kalau perlu tulislah sehari lima puluh kertas HVS bolak-balik. Lakukan hal tersebut saat melamun, sendirian, bingung, hingga bangun atau saat sebelum tidur.

3. Kepasrahan dalam doa

Memasrahkan diri dan memohon kepada Allah bahwa kita adalah hamba yang tidak memiliki apa-apa selain harapan, dengan menyatukan jemari, tekuk lutut bermohon kepada-Nya,tundukkan kepala dan ungkapkan apa yang menjadi kendala dalam hati. Hanya kepada Allah saja manusia bisa kembali dan dengan mencucurkan air mata jika seandainya menurut hati itu dapat mencairkan kebekuan jiwa. Cara ini merupakan adalah cara dalam upaya pendekatan spritual yaitu dengan memohon ampunan dari Allah SWT. 
Selain ditinjau dari sudut pandang psikologi pendidikan sebagai solusi, terapi dapat ditinjau juga dari aspek syariat Islam, yaitu dengan cara :

1. Penanaman keyakinan (aqidah/keimanan) yang kuat

Dalam Islam, ada enam keyakinan yang harus ditanamkan kepada manusia, yaitu:

a. Meyakini adanya Allah, dengan segenap sifat-sifatnya.

b. Meyakini malaikat dengan segala fungsi dan kedudukannya

c. Meyakini kitab-kitab yang pernah diturunkan Allah

d. Meyakini rasul-rasul-Nya dengan segenap contoh-contoh tauladannya

e. Meyakini hari kiamat beserta keadaan dan maksudnya

f. Meyakini ketentuan-ketentuan Ilahi terhadap kehidupan manusia dan seluruh alam semesta.

2. Menjaga rutinitas ibadah

Mulai dari ibadah wajib, shalat lima waktu, puasa bulan, zakat, dan haji hingga ibadah sunnah seperti sedekah dan shalat sunnah. Ibadah pokok ini merupakan kaitan langsung dengan proses penanaman keyakinan sebagai bagian dari pengisi spiritualisme jiwa manusia.

3. Memperbaiki sikap (akhlak)

Tingkah laku yang dimaksud adalah mulai dari menghindari hal-hal yang terlarang dalam hukum islam maupun hukum publik hingga melaksanakan hal-hal yang diperintahkan atau sekedar perbuatan yang memiliki keutamaan jika dilaksanakan. Perbuatan yang dilarang dalam hukum islam dan publik antara lain membunuh,mencuri, meminum minuman keras, berzina, menipu dan segala perbuatan yang hanya ditujukan untuk keuntungan diri demi kesenangan yang dapat merusak diri dan orang lain. Perbuatan yang termasuk terpuji dalam hukum islam dan publik antara lain jujur, baik hati, penyayang, penolong, rendah hati dan segala perbuatan yang berguna untuk diri, orang lain dan lingkungan. ${ }^{23}$

Terhadap pelaku penyimpangan seksual, seperti gay, lesbi, dan sejenisnya, juga terhadap pelaku penyimpangan perilaku, seperti waria atau sejenisnya, tindakan hukum dalam Islam sangat keras dan tegas. Tindakan hukum seperti itu harus dilakukan karena sesungguhnya mereka jelas-jelas telah melakukan penyimpangan perilaku dan seksual. Penyimpangan perilaku dan seksual ini tidak bisa dianggap sebagai hak asasi manusia. Dengan berlindung di balik HAM, tidak boleh penyimpangan seperti ini

\footnotetext{
${ }^{23}$ Jaja Suteja, Model Terapi Terhadap Perilaku Penyimpangan Transeksual Dalam Tinjauan Islam dan Psikologi Pendidikan, Jurnal Edueksos Vol IV No 1, Januari- Juni 2015,hlm 16-19
} 
dipelihara, karena justru penyimpangan seperti ini merusak kehidupan dan generasi umat manusia, termasuk diri pelakunya sendiri. Orang yang melakukannya berarti telah menyimpang seksnya. Orang yang menyimpang seksnya, berarti mengalami penyakit secara kejiwaan. ${ }^{24}$

Allah berfirman dalam surat Al-A'raf ayat 81

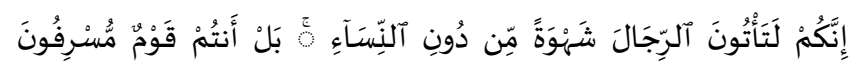

Sesungguhnya kamu mendatangi lelaki untuk melepaskan nafsumu (kepada mereka), bukan kepada wanita, malah kamu ini adalah kaum yang melampaui batas.

Menurut riwayat Abi al-Dunya, mula-mula kaum Nabi Luth menggauli anus kaum wanita, kemudian pindah dilakukan kepada kaum laki-laki atau melampiaskan nafsu seksnya kepada laki-laki. Dalam hal ini, seluruh ulama sepakat mengenai keharaman perbuatan homoseksual, pelakunya sangat dikutuk oleh agama Islam termasuk salah satu dosa besar. Bahkan perbuatan ini dapat digolongkan sebagai tindak pidana jarimah. ${ }^{25}$ Surat Al-Mu'minun ayat 5-6

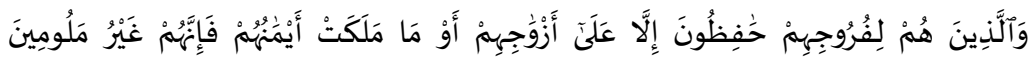

Dan orang-orang yang menjaga kemaluannya, Kecuali terbadap isteri-isteri mereka atau budak yang mereka miliki, maka sesungguhnya mereka dalam bal ini tiada tercela.

Dengan demikian, kaitannya dengan upaya menjaga kehidupan, maka penyaluran yang diperbolehkan oleh syariat hanyalah dengan istrinya. Bagi mereka yang tidak dapat mengendalikan diri atau menjaga syahwatnya tentu menikah adalah hal yang wajib, sedangkan berzina adalah hal yang diharamkan oleh Allah. Untuk itu Allah memberikan aturan berupa pernikahan agar manusia tidak terjebak dalam perzinahan.

\section{Penutup}

Perilaku deviasi seksual yang terjadi di pada beberapa kasus yang ditemukan terjadi bukan tanpa alasan. Gejala deviasi seksual yang ada dimungkinkan adanya orientasi penyimpangan seksual yang terjadi kepada seseorang yang tidak bisa disalurkan dengan baik. Orientasi seksual yang tidak bisa disalurkan menyebabkan adanya ketidak sehatan mental seseorang dalam menghadapi tugas perkembangan dalam mengekspresikan tindakan yang berupa hasrat. Adapun bentuk terapi yang bisa

\footnotetext{
${ }^{24}$ Al- Fikr, Wawasan al-Qur'an Tentang Deviasi Seksualitas dan Penanggulangannya, (Makassar :2002), hal 154

${ }^{25}$ Sayyid Sabiq, Fiqh al-Sunnah (Beirut: Dar al-Fikr, 1982) hlm 129
} 
dimungkinkan dalam meminimalisir tindakan penyimpangan seksual yang dilakukan berupa tidak otoriter pada diri, terapi sugesti, dan kepasrahan dalam doa dalam perilaku penyimpangan seksual yang dilakukan.

\section{Daftar Pustaka}

Al- Fikr, Wawasan al-Qur'an Tentang Deviasi Seksualitas dan Penanggulangannya, (Makassar :2002)

Anggoro, Purwadi Wahyu, Korban kekerasan seksual: Studi Kasus Penyimpangan Seksual Terhadap Anak Di Kepolisian Daerah Istimewa Yogyarata, Jurisprudence, Vol 5 No 1 Juni 2015

Umah, Khoiroh Teguh Saputro, Pendidikan Seks Terbadap Pencegahan Perilaku Penyimpangan Seksual Pada Remaja, Jurnal of Ners Community, Vol 7, No 1(2016)

Azwar dkk, Strategi Terapiutik Korban Homoseks: Studi Terbadap Pemikiran Ibnu Qayyim al-Janriyah, Islamic counseling Journal IAIN Curup, Vol 4 desember 2020

Arikunto, 2006, Prosedur Penelitian Suatu Pendekatan Praktek. Jakarta: PT. Rineka Cipta

Haryani, Mulya Dampak Pornografi Terhadap Perilaku Siswa Dan Upaya Guru Pembimbing Untuk Mengatasinya, Jurnal ilmiah Konselor, Vol 1, No 2(2012)

Insar Annur, Tinjauan Kriminologis Dan Hukum Islam Terhadap Deviasi Seks Dalam Hal Kejahatan Seksual, (Makasar: UIN Alauddin, 2012)

Junaedi, Didi 2010. 17+: Seks Menyimpang. Jakarta:Semesta Raya Merdeka

Kartono, Kartini Psikologi Abnormal Dan Abnormalitas Seksual, (Bandung: cv. Mandar Maju, 2009)

Morgan, Clifford Thomas, 1986, Introduction to Psychology (International Edition), McGraw-Hill Book Co, Singapore

Notosoedirdjo, Moeljono, Latipun, Kesehatan Mental, Konsep dan Penerapan, Malang: UMM Press, 2014

Sarwono, Sarlito 2002. Psikologi Remaja. Jakarta: Raja Grafindo Persada

Sayyid Sabiq, Fiqh al-Sunnah (Beirut: Dar al-Fikr, 1982)

Sundari,Siti, Kesehatan Mental Dalam Kebidupan (Jakarta: Rinekan Cipta, 2018) 
Suteja, Jaja Model Terapi Terhadap Perilaku Penyimpangan Transeksual Dalam Tinjauan Islam dan Psikologi Pendidikan, Jurnal Edueksos Vol IV No 1, Januari- Juni 2015

Yasir, Dekonstruksi Seksualitas Poskolonial, (Yogyakarta: LKIS, 2004)

Yusuf, Syamsu, Kesehatan Mental, Perspektif Psikologis dan Agama (Bandung: PT Remaja Rosdakarya, 2018)

\section{Sumber internet}

https://regional.kompas.com/read/2011/01/19/19530783/10.bocah.ditemuka n.jadi.korban.sodomi.?page $=$ alli

https://news.detik.com/berita-jawa-barat/d-5191514/pencurian-celana-dalamwanita-di-cianjur-isu-kolor-ijo-menyeruaki

https://news.detik.com/berita-jawa-barat/d-5191514/pencurian-celana-dalamwanita-di-cianjur-isu-kolor-ijo-menyeruaki

https://www.cnnindonesia.com/nasional/20200731084638-20530908/kronologi-heboh-kasus-fetish-gilang-bungkus-kain-jarik

https://amp.kompas.com/lifestyle/read/2010/05/01/20363317/bahaya.kecan duan.seksi 